\title{
Students' Choice Intention of a Higher Learning Institution : An Application of the Theory of Reasoned Action (TRA)
}

\author{
T. RAMAYAH, AIZZAT MOHD NASURDIN, \\ MOHD NASSER MOHD NOOR \& HAJEMI HASSAN \\ School of Management \\ Universiti Sains Malaysia
}

\begin{abstract}
The purpose of the present study is to identify the determinants of upper secondary level students' intentions whether to choose a private or a public higher learning institution. Ajzen and Fishbein's (1980) Theory of Reasoned Action was used as the basis for this study. The theory posits that the immediate determinant of behavior is intention. Intention is determined by the weighted attitude toward the behavior and the weighted subjective norm. Combinations of beliefs, evaluations, and motivation to comply determine attitude and subjective norm towards behavior. Salient beliefs related to attitude towards both private and public institutions of higher learning and salient beliefs related to the subjective norm for both private and public higher learning institutions were identified. The sample consisted of 132 students whose age ranges from 16 years to 24 years. Hypotheses generated in accordance to the theory were confirmed. The findings also showed that attitude toward behavior and subjective norm explained $75 \%$ of the variance in behavioral intention for both private and public institutions of higher learning. Attitude toward behavior had a greater relative weight $(\beta=0.539)$ compared to the subjective norm ( $\beta=0.401)$ for both private and public higher learning institutions. Implications of the above findings are discussed.
\end{abstract}

\begin{abstract}
ABSTRAK
Kajian ini bertujuan mengenal pasti penentu bagi niat pelajar peringkat menengah atas sama ada untuk memilih institusi pengajian tinggi swasta ataupun awam. Teori Tindakan Beralasan oleh Ajzen dan Fishbein (1980) digunakan sebagai asas kajian ini. Teori ini mencadangkan penentu paling hampir kepada gelagat ialah niat. Niat ditentukan oleh sikap terhadap gelagat dan norma subjektif yang dipertimbangkan. Gabungan kepercayaan, penilaian, dan motivasi untuk mengikut menentukan sikap dan norma subjektif terhadap gelagat. Kepercayan yang kuat berkaitan sikap serta kepercayan yang kuat berkaitan dengan norma subjektif terhadap kedua-dua institusi pengajian tinggi swasta dan awam telah dikenal pasti. Sampel kajian terdiri daripada 132 pelajar berumur antara 16 tahun sehingga 24 tahun. Hipotesis yang dihasilkan berdasarkan teori telah berjaya dibuktikan. Penemuan kajian menunjukkan sikap terhadap gelagat dan norma subjektif menjelaskan 75\% daripada variasi dalam niat gelagat untuk kedua-dua institusi pengajian tinggi swasta dan awam. Sikap terhadap gelagat mempunyai pemberatan relatif yang lebih besar $(\beta=0.539)$ berbanding dengan norma subjektif ( $\beta$ $=0.401$ ) bagi kedua-dua institusi pengajian tinggi swasta dan awam. Implikasi penemuan dibincangkan.
\end{abstract}




\section{INTRODUCTION}

Consumers are constantly faced with the need to make decisions. For instance, every consumer at one point in time will have to choose among different products and services, models and brands, among different available styles and sizes, among the different stores or outlets, and so on. The issue of choice and the process through which individuals make their choices are a prime concern for consumer researchers. Recognition of the importance of consumer behavior has led numerous researchers to examine the factors that influence a consumer's choice more closely. Numerous studies conducted by scholars within this field have pointed out that a combination of the cognitive, motivational, and affective processes underlie every consumer's decision (Schiffman \& Kanuk, 1994). These processes are greatly influenced by the interplay of three factors. The first factor, known as the internal factor, relates to the individual's needs, perceptions, and attitudes. Additionally, the consumer's demographic characteristics, life-style, and personality traits may also influence his/her decision. The two other remaining factor, categorized as external factors are, environmental influences and marketing strategies respectively (Assael, 1992). Environmental influences include culture, social class, face-to-face groups, and situation. Marketing strategies, on the other hand, represent variables within the control of the marketer namely; product, price, promotion, and distribution.

Changes in demography, economy, and public policies in Malaysia have transformed the local higher educational marketplace. With greater number of players offering educational products, competition for buyers has increased significantly. Today, it can be observed that the local educational market is at the initial stage of transition from a seller's market to a buyer's market in which buyers will have more bargaining power and can afford to become very demanding in choosing educational products. This is an era of rising student's consumerism, where students are designated as principal consumers of the market-oriented education system. As competition increases, the application of marketing in the field of higher education also increases (Kotler, 1994, Kotler \& Andreason, 1991, Kotler \& Fox, 1985).

Educational marketers must attempt to answer this fundamental question: How do students choose a particular higher learning institution from the enormous number of alternatives? This question parallels a common marketing question in business: How do consumers choose a particular product or service? The role of attracting consumers to a product and having those consumers make a purchase is the most important function of marketing. With regards to overt purchasing response, it is a matter of utmost importance to understand how students choose the best institution of higher learning, the kind of information that will influence the decision, and their attitude toward this behavior. Since (Holland's, 1958) initial investigation on factors used by potential students in selecting a higher learning institution, numerous education studies have sought to learn why students select a particular higher learning institution. Most of these researchers agreed that the fundamental idea is that students will select those institutions that match their selection criteria academically, socially, and financially (Brown, 1991). In Malaysia, a number of studies that used the premise of public versus private services has been conducted. For example, (Ahmed, 1996) examined the important factors in the services provided by both public and private maternity clinics that determine a consumer's final preference. The current research can be considered as another extension of public versus private theme. In this study, the services provided by higher learning institutions will be the subject of interest. For reasons of simplicity and convenience, higher learning institutions consisting of all universities and colleges in Malaysia, have been grouped as either "Public Higher Learning Institution" (IPTA) or "Private Higher Learning Institution" (IPTS). In the local higher learning education sector, public institutions have been the dominant players in the market with the blessings from the government. It took years for these public universities and community colleges to establish themselves and build their reputation. The private higher learning institutions, on the other hand, started to make an impact in the education marketplace in the late 1990s. Even though they can be 
considered at the infancy stage, these private institutions have much to offer and will become strong competitors to the public institutions in the near future. Nevertheless, the public higher learning institutions in many aspects will still remain to be the yardstick for private institutions of higher learning.

The question being posed here is about students as principal decision-makers in having to choose between public and private institutions of higher learning. It is important to acknowledge that the extent of choice is made available to incorporate the academic factors (quality of education, excellent lecturers, academic reputation), financial factors (study fees, lodging and transportation costs), and social factors (social environment, co-curriculum, and sport activities). Therefore, the focus of this study is to investigate the factors that influence students' choice of a public or private institution of learning.

\section{LITERATURE REVIEW}

\section{The Education Industry of Malaysia}

In recent years, the local education industry under the guidance and jurisdiction of the Ministry of Education, has undergone an interesting state of metamorphosis. Traditionally, the demand for academic products is greater than what the industry can supply. During this period, the existing route to acquire a higher academic qualification is rather limited. In line with the aspiration of creating a knowledgeable Malaysian society, the government has initiated the move to liberalize the education industry. This development is further boosted by the government's decision to establish Malaysia as a center for academic excellence within the Asian region.

The liberalization in the government policy with regard to education has led to a significant increase in the number of players providing education services in the marketplace. While educationists welcome the establishment of more institutions, and the wider choices available to the students, they are also concerned about the challenges that these new institutions are facing. One of the most critical issue is the number of students enrolled in each institution. In 1999, there were
224,738 students registered in local private institutions. Among them, 215,850 were at private colleges, 8,185 at private universities, and 703 at branch campuses of foreign universities (The Sun, 16 Jan. 2000). Although the total enrolment appears to be large, the fact is that most private colleges are not operating at their capacity. In other words, there are not enough students to fill the current number of private higher learning institutions. As far as the public higher learning institutions are concerned, the enrolment of students into these institutions is not a matter of concern at least for the time being. Nevertheless, if the public higher learning institutions do not undertake the necessary steps in responding to changes in the education marketplace, the decline in enrolment will become a major future concern.

\section{Public Higher Learning Institutions}

According toAhmat, (1980), "As an integral part of society, the public higher education institutions are influenced and shaped by the economic, sociocultural and political realities that surround them". The government expects the public higher education institutions to play a key role in the economic and social development of the country, thereby, contributing toward nation building. In the need for close relationship between education and national development, the main objectives of public higher education institutions are: 1) Assisting in the promotion of national integration and unity through their teaching as well as non-curricular programs, and through the use of the national language, that is, the Malay language as the principal medium of instruction, 2) Meeting the manpower needs of the nation with greater emphasis on science and technology, 3) Rectifying existing imbalances in educational opportunities among racial and income groups, rural and urban areas, and between developed and less developed regions, and 4) Studying and finding solutions to serious national problems such as health and environment, employment and human resources development, housing, and the like, through research and development.

All these higher education institutions are publicly funded, in full or in part, and administered by the Federal Government through its vari- 
ous ministries, especially the Ministry of Education. With special incentives provided by the government, there is no sign that the number of students enrolled into public institutions will become a major concern, at least not in the immediate future. The year 1998 saw the expansion of most local public universities by way of new programs being offered both at the undergraduate and postgraduate levels, owing to increase demand (Nalliah \& Thiyagarajah, 1999). For example, the International Islamic University announced new engineering programs such as Material Engineering, Aerospace Engineering, Automotive Engineering, Biotechnology Engineering, Telecommunication Engineering, and Biomedicine Engineering. Additionally, Universiti Sains Malaysia announced its dentistry program and three new Master's degree courses in Screen Studies, Corporate Communication and Advertising (New Straits Times, 29 Nov. 1998).

\section{Private Higher Learning Institutions}

One of the immediate results of the liberalization in the education sector is the springing up of private higher education facilities. The desire for education and the uncertainty of access into local tertiary institutions continues to fuel this development. By the end of 1999, there were already 600 local private institutions that comprised of private colleges, private universities, and branch campuses of foreign universities (The Sun, 16 Jan. 2000). This number is expected to rise further in the years ahead. The establishment of more academic institutions has provided a wider choice available to students. Most of the local private institutions especially private colleges are offering foreign universities' programs through franchising agreements. Another significant development in private higher learning education that took place in 1998 was the setting up of offshore campuses of foreign universities in Malaysia. The first branch campus of a foreign university is the Monash University Sunway campus which opened its door to its pioneer batch of 450 students on 20 July 1998 (News Straits Times, 21 Jul. 1998).

The role of private higher learning institutions is to complement the public institutions in providing education opportunities for all Malaysian students and in establishing Malaysia as a centre for excellence education. Unlike the public institutions, the private higher learning institutions receive hardly any incentives from the government. At present, there is no national longterm master plan for private education. This has made it difficult for private institutions to chart their courses and carry out their plans with certainty. Additionally, in ensuring the quality of service rendered, all private higher learning institutions are required by the government to get the endorsement from the National Accreditation Board (LAN). LAN is a body that among others assesses an institution's credibility in terms of its courses, facilities and the quality of its academic staff (The Sun, 16 Jan. 2000).

\section{Higher Learning Institution Choice Behavior} The study of higher learning institution/college choice behavior is of great practical importance for administrators in promoting greater effectiveness in the planning and forecasting of students enrolment into their institutions and in influencing the college-going decision-making process of desired students. In general, the study of higher learning institution/college choice behavior can be classified into two levels, the macro-level and the micro-level. The study of enrolment behavior of students in groups (macro-level) indicates how changes in environmental and institutional characteristics affect an institution's total enrolment. The study of the college/higher learning institution choice behavior of individual students (micro-level) indicates the way in which environmental, institutional, and student characteristics affect a student's choices about whether or not to attend college and which college or higher learning institution to attend. It is the result of these studies, which provide the fundamental knowledge bases for enhancing the effectiveness of enrolment planning activities and students' marketing and recruitment activities (Hossler, 1984).

The greatest contribution of the micro-level studies of higher learning institution choice behavior is their ability to estimate the effects of institutional and student characteristics on the probability that a particular consumer will choose 
a particular institution. Understanding the enrolment effects of such characteristics can help enrolment managers tailor their institution's marketing mix with regard to programs offered, fees charged, promotion, and location. The increasingly competitive and complex nature of making choices regarding higher learning institution/college and the expansion of the marketing approach to student recruitment help enhance the desire to better understand and subsequently influence the college choice process. As such, many researchers and practitioners have tried to develop more detailed specifications, or models, of the higher learning institution choice process. Many researchers have relied on some variation of (Jackson's, 1982) three-phase model of the college choice process. The college aspiration formation stage is the one in which fundamental educational aspirations are formed and may last from early childhood through high school and beyond. The college/higher learning institution search and application phase includes acquiring and examining information about institutions and the identification of a limited number of institutions whom one wish to apply. The higher learning institution/college selection and attendance phase involves the evaluation of the alternatives and the final selection of a particular institution. According to (Litten et al., 1983), institutions engaged in market research will usually examine the behavior pattern of student enrolment during this phase.

\section{Important Characteristics of Higher Educa- tion Institutions}

There are several characteristics of the higher education institutions that affect choice decisions among students. According to (Hossler \& Gallagher,1987), institutional variables have an impact on students' choice of higher education institutions. One of the most comprehensive studies in this area relates to that conducted by (Litten and Brodigan, 1982) on 3000 high school seniors in six large metropolitan cities in the United States. (Litten \& Brodigan, 1982) asked students to rate a list of 25 institutional characteristics according to their importance, in deciding which college or university to apply. By drawing the students' attention to the application process, researchers fo- cused the questions and the responses on those particular institutional characteristics considered important during the search and application phase of the choice process. Students gave highest ranking to issues such as financial, field of study, general academic reputation, location, social atmosphere, faculty teaching reputation, academic standard, and career prospect. This finding is consistent with those of an earlier study by (Lewis \& Morrison,1975), who found six characteristics most frequently utilized to evaluate institutions of higher education: special academic programs, cost, location, size, general reputation, and distance from home. Similarly, (Gilmour et al., 1978) found that the four most important college attributes throughout all of the phases of the college choice process were cost, location, programs, and quality. Additionally, several recent studies have been undertaken in this area. For instance, (Absher \& Crawford, 1996) conducted a study of university students at the University of North Alabama whereby twenty-nine college image components were identified based on focus group interviews and the review of literatures. These components were later investigated by measuring the importance of each in predicting a student's selection of a higher learning institution. These selection variables were ranked from the most important to the least important based on the mean value. The results of this investigation indicated that the five variables rated as very important out of the 29 variables identified were overall quality of education, types of academic program, tuition and fees, overall reputation of the institution, and faculty qualification. In another similar study conducted by (Stanley \& Reynolds, 1994), value of qualification, recognition, broad range of courses, and proximity to home have been expressed by students as important factors that influence their institutional preferences. Earlier, (Hossler \& Gallagher, 1987) carried out a study to investigate the relative importance of certain college characteristics in influencing high school students' choice regarding a prospective college. Their results indicated that teacher attributes, area of study offered, cost and academic reputation were ranked the highest in terms of importance among the list of college characteristics investigated. The other characteristics include student population, sports 
and extracurricular programs, and distance to commute.

\section{THEORETICAL FRAMEWORK AND HYPOTHESIS}

\section{Theory of Reasoned Action}

The theory of reasoned action proposes that behavior results from the formation of specific intentions to behave (Ajzen \& Fishbein, 1980). According to the TRA model, two major factors determine behavioral intentions, one personal in nature and the other reflects social influence. The personal factor is termed attitude toward behavior. It refers to a person's judgment on whether performing the behavior is good or bad, and whether he is in favour of or against performing the behavior. The social factor is termed subjective norm. It is a person's perception of the social pres- sures imposed on him to perform or not to perform the behavior in question. According to the theory, behavioral beliefs underlie a person's attitude toward the behavior. In other words, behavioral beliefs relate to a person's beliefs that a particular behavior leads to certain outcomes and his/her evaluation of these outcomes. Similarly, normative beliefs underlie a person's subjective norm. In other words, normative beliefs relate to a person's beliefs that specific individuals or groups think he/she or they should perform the behavior and his/hers/their motivation to comply with the specific referents. Thus, behavioral beliefs, and evaluations of behavioral outcomes lead to attitude toward behavior whereas normative beliefs, and the motivation to comply with specific referents lead to subjective norm. Both the attitudinal and subjective components determine a person's intention, which in turn, is the precursor to behavior.

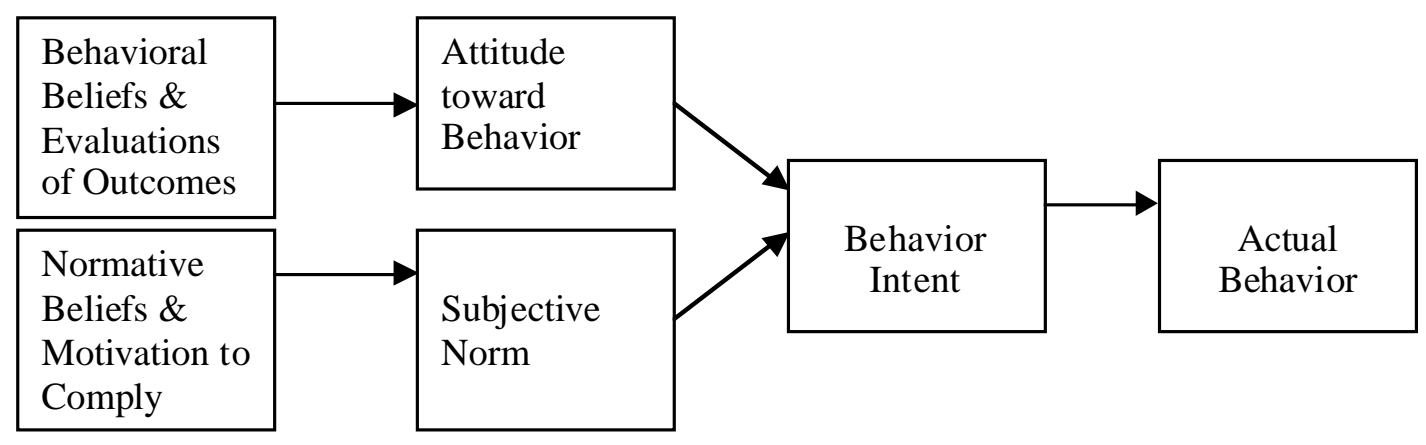

\section{Figure 1}

Theory of Reasoned Action

Source: Ajzen, I., and Fishbein, M. (1980). Understanding attitudes and predicting social behavior, New Jersey:Prentice-Hall.

Algebraically, the TRA model (Ajzen \& Fishbein, $1980)$ is expressed as:

$\mathrm{B} \sim \mathrm{I}=\left(\mathrm{A}_{\mathrm{B}}\right) \mathrm{w}_{1}+(\mathrm{SN}) \mathrm{w}_{2}$
Where:

$$
\begin{aligned}
\mathrm{B}= & \text { behavior } \\
\mathrm{I}= & \text { the person's intention to } \\
& \text { perform the behavior }
\end{aligned}
$$




$$
\begin{array}{ll}
\mathrm{A}_{\mathrm{B}}= & \text { the person's attitude toward } \\
& \text { performing behavior } \\
\mathrm{SN}= & \text { subjective norm } \\
\mathrm{w}_{1} \text { and }_{\mathrm{W} 2}= & \text { empirically determined } \\
& \text { weights }
\end{array}
$$

Attitude toward behavior refers to the person's judgment on whether performing the behavior is good or bad. The subjective norm reflects the person's perception of social pressures put on him/her to perform or not to perform the behavior in question. According to the theory, attitudes are a function of beliefs. In general, a person who believes that performing a given behavior will lead to positive outcomes thus will hold a favourable attitude toward performing the behavior. Similarly, a person who believes that performing a given behavior will lead to negative outcomes thus will hold an unfavourable attitude toward performing the behavior. According to the TRA model, attitude toward the behavior is determined by the beliefs that the behavior leads to certain outcomes, and by the person's evaluation of these outcomes.

Algebraically, it can be written as

$$
A_{B}=\sum b_{i} e_{i, \text { for } i=1 \text { to n. }} \text {. }
$$

Where:

$$
\begin{aligned}
\mathrm{A}_{\mathrm{B}}= & \begin{array}{l}
\text { attitude toward performing } \\
\text { the behavior }
\end{array} \\
\mathrm{b}_{\mathrm{i}}= & \begin{array}{l}
\text { the person's belief that } \\
\text { performing the behavior will } \\
\text { result in outcome } i
\end{array} \\
\mathrm{e}_{\mathrm{i}}= & \begin{array}{c}
\text { the person's evaluation of } \\
\text { outcome } i
\end{array} \\
\mathrm{n}= & \text { the number of beliefs }
\end{aligned}
$$

Additionally, subjective norms are a function of normative beliefs. In other words, a person who believes that most referents with whom he/she is motivated to comply with think he/she should perform the behavior will perceive social pressure to do so. Conversely, a person who believes that most referents with whom he/she is motivated to comply with think he/she should not perform the behavior will perceive social pres- sure to avoid performing the behavior. According to the TRA model, the general subjective norm is determined by the perceived expectation of specific referent individuals or groups, and by the person's motivation to comply with those expectations. norm is:

The equation for obtaining the subjective

$$
\begin{aligned}
& \mathrm{SN}=\sum \mathrm{NB}_{\mathrm{j}} \mathrm{MC}_{\mathrm{j}} \text {, for } \mathrm{j}=1 \text { to } \mathrm{n} . \\
& \mathrm{SN}=\text { subjective norm } \\
& \mathrm{NB}_{j}=\text { the normative belief that a } \\
& \text { reference group } j \text { thinks that the } \\
& \text { person should or should not } \\
& \text { perform the behavior. } \\
& \mathrm{MC}_{\mathrm{j}}=\text { the motivation to comply with } \\
& \text { the influence of referent } j \text {. } \\
& \mathrm{n}=\text { the number of relevant reference } \\
& \text { groups of individuals. }
\end{aligned}
$$

\section{TRA Extended into the Choice Domain}

As originally developed and typically used, the (Fishbein \& Ajzen's, 1975) model focuses on the determinants and performances of a single behavior. (Ajzen \& Fishbein,1980) argued that not considering the possibility of choosing among alternative behaviors represents a serious omission in the model. The presence of choice can be expected to diminish the ability of accurately predicting behavior by using a measure of intention to perform a single behavior as was originally proposed in the model, and as has been done frequently in research using this model. Sheppard, (Hartwick, \& Warshaw,1988) suggested that there are two possibilities of how and where this attenuation of prediction due to choice might occur. The first possibility involves an intention comparison process whereby individuals form an intention toward each alternative based on their attitudes and subjective norm toward the alternative. They then compare the strength of their intentions toward each of the alternatives, choosing and performing the alternative with the strongest intention. Thus, choice is seen as a process of comparing and selecting among intention 
associated with each alternative in the choice set. This is the process essentially adopted by (Fishbein \& Ajzen, 1975) as they extended their model into the choice domain. The other possibility involves an attitude comparison process, whereby, individuals assess their attitude and subjective norms toward each alternative and select the one with the most positive attitude and subjective norm. Based on this choice, they form an intention to perform that one alternative and subsequently perform the behavior. Thus, choice is seen as a process of comparing and selecting among the attitudes and subjective norms associated with each of the alternatives in the choice set.

Although it is not conclusive, it is interesting to note that the results obtained from the metaanalysis conducted by (Sheppard et al., 1988) showed that neither of the suggested extensions to the model fared inferior to the original (Fishbein \& Ajzen, 1975) model. They found that the presence of a choice among alternatives did not weaken the predictive utility of the model. Rather, quite the opposite occurred-overall, the model performs better when used to study activities involved choice. Thus, it would seem that the (Ajzen $\&$ Fishbein, 1980) model has strong predictive utility, even when utilized to investigate situations and activities that do not fall within the boundary conditions originally specified for the model. Clearly, further modifications and refinements are still necessary when it is still not clear why the model better predicted activities involved choice. However, for the moment, it would appear that the (Ajzen \& Fishbein, 1980) model works adequately in choice situations. Thus, this TRA model was adopted in this investigation as shown in Figure 2.

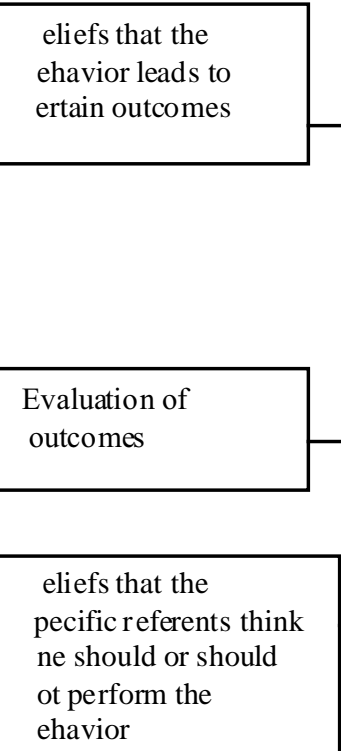

otivation to comply

ith the specific

eferents

Figure 2

Research Model 
Figure 2 was developed based on the theory of reasoned action (Ajzen \& Fishbein, 1980). As shown in Figure 2, behavioral beliefs relate to a person's beliefs about choosing a higher learning institution (in this case, public (IPTA) or private (IPTS)). Evaluation of outcomes refers to a person's judgment about the attributes associated with a particular institution of higher learning (IPTA or IPTS). Since there are two choices to be made, the differential scores will be taken. Thus, a person's attitude toward choosing either IPTA or IPTS will be a function of his/her behavioral beliefs and his/her evaluation of the outcomes. Normative beliefs, on the other hand, relate to a person's beliefs concerning why a specific referent (such as parents) think he/she should or should not choose a particular institution of higher learning (IPTA or IPTS). Motivation to comply refers to a person's likelihood to comply with the wishes of the specific referent. Since there are two choices to be made, differential scores will also be taken. Thus, a person's subjective norm toward choosing either IPTA or IPTS will be a function of his/ her normative beliefs and his/her own motivation to comply.

The hypotheses conjectured in this study are as follows:

$\mathrm{H}_{1}$ : $\quad$ The intention to choose a higher education operator (private or public) is influenced by a person's attitude towards the behavior and his/her subjective norm.

$\mathrm{H}_{2}$ : The more positive is the attitude towards the behavior, the greater is the intention to perform the behavior.

$\mathrm{H}_{3}$ : The more positive is the subjective norm, the greater is the intention to perform the behavior.

$\mathrm{H}_{4}$ : $\quad$ Behavioral intention can be used to discriminate whether a person will choose a private or a public higher education operator.

\section{METHODOLOGY}

\section{Sample, Procedure, and Instruments}

The population for this study consists of all upper secondary school students in the state of Penang. A sample of 200 students was selected via proportionate sampling. The instruments to measure the study variables were derived from published literatures (for example, Absher \& Crawford, 1996; Gilmour et al., 1978; Lewis \& Morrison, 1975; Litten \& Brodigan, 1982; Stanley \& Reynolds, 1994). A five-point Likert scale response format was used ranging from (1) "most likely" to (5) "most unlikely".

\section{RESULTS}

From a total of 200 questionnaires, 132 responses were obtained representing a response rate of $66 \%$. The sample profile can be observed from Table 1 .

Table 1

Sample Profile

\begin{tabular}{|l|c|c|}
\hline \multicolumn{1}{|c|}{ Demographic elements } & Frequency & Percentage (\%) \\
\hline Gender & & \\
Male & 54 & 40.9 \\
Female & 78 & 59.1 \\
& & \\
\hline
\end{tabular}


(continued)

\begin{tabular}{|c|c|c|}
\hline Demographic elements & Frequency & Percentage (\%) \\
\hline $\begin{array}{l}\text { Age } \\
17 \text { years and below } \\
18 \text { years } \\
19 \text { years } \\
20 \text { years and above }\end{array}$ & $\begin{array}{l}35 \\
31 \\
48 \\
18\end{array}$ & $\begin{array}{l}26.5 \\
23.5 \\
36.4 \\
13.6\end{array}$ \\
\hline $\begin{array}{l}\text { Race } \\
\text { Malay } \\
\text { Chinese } \\
\text { Indian }\end{array}$ & $\begin{array}{l}46 \\
55 \\
31\end{array}$ & $\begin{array}{l}34.8 \\
41.7 \\
23.5\end{array}$ \\
\hline $\begin{array}{l}\text { Education Level } \\
\text { SRP/PMR } \\
\text { SPM/SPMV } \\
\text { STPM }\end{array}$ & $\begin{array}{l}18 \\
77 \\
37\end{array}$ & $\begin{array}{l}13.6 \\
58.4 \\
28.0\end{array}$ \\
\hline $\begin{array}{l}\text { Types of School } \\
\text { S.M.Biasa } \\
\text { S.M.Berasrama Penuh } \\
\text { S.M.Vokasional } \\
\text { S.M.Teknik } \\
\text { S.M.Agama }\end{array}$ & $\begin{array}{r}90 \\
5 \\
16 \\
5 \\
16\end{array}$ & $\begin{array}{r}68.2 \\
3.8 \\
12.1 \\
3.8 \\
12.1\end{array}$ \\
\hline $\begin{array}{l}\text { Working Status } \\
\text { Part time work } \\
\text { Unemployed/Studying }\end{array}$ & $\begin{array}{r}7 \\
125\end{array}$ & $\begin{array}{r}5.3 \\
94.7\end{array}$ \\
\hline $\begin{array}{l}\text { Monthly income } \\
\text { (Individual/Parent/Guardian's Income) } \\
\text { RM500 and Below } \\
\text { RM501-RM1000 } \\
\text { RM1001-RM1500 } \\
\text { RM1501-RM2000 } \\
\text { RM2001-RM2500 } \\
\text { RM2501 and Above }\end{array}$ & $\begin{array}{r}33 \\
45 \\
17 \\
14 \\
9 \\
14\end{array}$ & $\begin{array}{r}25.0 \\
34.1 \\
12.9 \\
10.6 \\
6.8 \\
10.6\end{array}$ \\
\hline $\begin{array}{l}\text { Modes of financing study } \\
\text { Self support (from income) } \\
\text { Government loan/Scholarship } \\
\text { Family support } \\
\text { (parent/guardian's income) }\end{array}$ & $\begin{array}{r}7 \\
24 \\
101\end{array}$ & $\begin{array}{r}5.3 \\
18.2 \\
76.5\end{array}$ \\
\hline
\end{tabular}


Table 2

Reliability Coefficients

\begin{tabular}{|l|c|c|c|}
\hline Variable & Number of Items & Items Deleted & Alpha \\
\hline Beliefs of outcome (IPTS) & 14 & - & 0.82 \\
Beliefs of outcome (IPTA) & 14 & - & 0.80 \\
Beliefs of others (IPTS) & 7 & - & 0.73 \\
Beliefs of others (IPTA) & 7 & - & 0.81 \\
Evaluation of Outcome & 14 & - & 0.78 \\
Motivation to Comply & 7 & - & 0.73 \\
\hline
\end{tabular}

From Table 2, alpha coefficients ranged from 0.73 to 0.82 , which exceeded (Nunally's, 1978) minimum requirement of 0.7 .

We further explored the pattern of respondents' answers toward each element of an attitude component and its respective ranking. Respondents gave the highest ranking to the attribute of having a good social and learning atmosphere in private higher learning institution (IPTS), whereas the convenience of location was the second highest ranked. On the other hand, the cost factor received the lowest ranking for IPTS. For the public higher learning institution (IPTA), the attribute of having a broad range of courses was ranked the highest whereas having a good academic reputation received the second highest ranking. On the other hand, proximity to home was ranked the lowest.

For evaluation of the outcome, the attribute pertaining to offer a broad range of courses has been ranked as the most important attribute while the large student population has been considered as the least important attribute.

For subjective norm, respondents who thought of entering into IPTS have given the highest ranking to opinions from friends who have enrolled in the particular private institution of higher learning (mean moving toward most likely). On the other hand, the opinion derived from one's working colleagues and neighbours received lower rankings (value of mean moving toward most unlikely). In contrast, respondents who thought of entering into IPTA have given the highest ranking to opinions from their own families (mean moving toward most likely). This group also ranked the opinion derived from one's working colleagues and neighbours with lower rankings (value of mean moving toward most unlikely).

In terms of the importance of referent, it was shown that families, teachers, and education counselors' opinions have been regarded as important by respondents in choosing a particular institution of higher learning (IPTA or IPTS).

In order to demonstrate attitude toward behavior and subjective norm are the predictors of intention of choice decision on the choice of IPTS or IPTA, the independent assessment of intention, attitude toward behavior and subjective norm were obtained for IPTA and IPTS choices. Given the primary concern of this study is to understand the choice decision between the two types of higher education system, the differential scores for attitudes, subjective norms, and intentions were computed. The differential scores were obtained by subtracting the scores for IPTA from that of the IPTS's. Subsequently, multiple regression analysis was conducted. 
Table 3

Results of Multiple Regression for Intention vs. Attitude and Subjective Norm

\begin{tabular}{|lc|}
\hline Independent Variable & Std Beta \\
\hline Attitude & $0.539^{* *}$ \\
Subjective Norm & $0.401^{* *}$ \\
\hline $\mathrm{R}^{2}$ & 0.75 \\
Adj $\mathrm{R}^{2}$ & 0.74 \\
F Value & $210.40^{* *}$ \\
Durbin Watson & 1.91 \\
& \\
\hline \multirow{*}{**}{$\mathrm{p}<0.01$} & \\
\hline
\end{tabular}

The R-square value of 0.75 indicates that $75 \%$ of the variance in the dependent variable (differential intention) can be explained by the two independent variables (attitude and subjective norm). This finding provided support for the first hypothesis of this research. In terms of the relative predictive power of the two independent variables, namely, attitudes towards the behavior and subjective norm on the choice decision to pick IPTA or IPTS, it can be observed that the beta weight for attitude ( 0.539$)$ was larger than the beta weight of subjective norm (0.401). This suggests that a person's personal beliefs system plays a more dominant role in influencing choice decision toward choice of IPTA or IPTS as opposed to perceived expectations of significant others or reference groups and peer motivation.

Additionally, the results obtained from Table 3 provided evidence to support the second and the third hypothesis of the study. The standardized beta coefficient for the attitude component is positive (0.539). This value implies that the more positive is the attitude, the greater is the intention to perform the behavior. Similarly, the results obtained from Table 10 provided evidence to support hypothesis 3 of this investigation. The standardised beta coefficient for the subjective norm component is again positive $(0.401)$ which implies that the more positive is the subjective norm, the greater is the intention to perform the behavior.

Discriminant analysis was undertaken to test whether behavioral intention can be discriminated in accordance to whether a person will choose IPTS, Undecided or IPTA. Respondents' choice decisions were classified as group 1 (IPTS) and group 2 (IPTA). Data was split using a 60-40 ratio for analysis and validation. This is done to test the internal validity of the model and assess its predictive accuracy. The summary results obtained from the discriminant analysis are depicted in Table 4 and Table 5.

As can be observed from Table 4 and Table 5 , a discriminant model is said to exist given the chi-square value of 95.60 is significant $(\mathrm{p}=0.000)$. The hit ratio was $95.2 \%$ (analysis sample) and 98.0\% (holdout sample). This indicates that by measuring intention, we can accurately classify respondents according to their choice decision with the 2 given percentages above. Table 6 shows the comparison of the goodness of measure. As can be seen, the hit ratio for both the analysis sample and the holdout sample is higher than the maximum chance and proportional chance. According to Hair et al., (1998), since the hit ratio was higher than both the maximum chance criterion and the chance criterion, the model is said to have acceptable level of predictive accuracy. Press 
Table 4

Hit Ratio For Cases Selected In The Analysis (Analysis Sample)

\begin{tabular}{|l|c|c|c|}
\hline \multirow{2}{*}{ Actual Group } & \multirow{2}{*}{$\begin{array}{c}\text { No. of } \\
\text { Cases }\end{array}$} & \multicolumn{2}{|c|}{ Predicted Group Membership } \\
\cline { 2 - 4 } & IPTS & IPTA \\
\hline IPTS & 5 & $\begin{array}{c}4 \\
(80.0)\end{array}$ & $\begin{array}{c}1 \\
(20.0)\end{array}$ \\
\hline IPTA & 71 & 2 & 69 \\
$(2.8)$ & $(97.2)$ \\
\hline
\end{tabular}

Percentage of "grouped" cases correctly classified: $95.2 \%$

Table 5

Hit Ratio For Cases Not Selected In The Analysis (Holdout Sample)

\begin{tabular}{|l|c|c|c|}
\hline \multirow{2}{*}{ Actual Group } & \multirow{2}{*}{$\begin{array}{c}\text { No. of } \\
\text { Cases }\end{array}$} & \multicolumn{2}{|c|}{ Predicted Group Membership } \\
\cline { 2 - 4 } & 5 & IPTS & IPTA \\
\hline IPTS & 51 & $\begin{array}{c}5 \\
(100)\end{array}$ & $\begin{array}{c}(0) \\
\text { IPTA }\end{array}$ \\
& 5 & $\begin{array}{c}1 \\
(1.9)\end{array}$ \\
& & & $(98.0)$ \\
\hline
\end{tabular}

Percentage of "grouped" cases correctly classified: $98.0 \%$

Q of 65.33 (analysis sample) and 52.07 (holdout sample) which are greater than Table value $=6.635$ $\left(\chi^{2}, \mathrm{df}=1, \alpha=0.01\right)$. Thus, it can be concluded that the predictions are significantly better than chance. The discriminant function has a canonical squared correlation equal to 0.4096 and is statistically significant with Wilks' Lambda $=0.64$, $(p=0.000)$ indicating that $40.96 \%$ of the variance in choice can be explained by the discriminant function. In sum, the findings obtained from the discriminant analysis indicate that intention is a precursor to performing a particular behavior. This result provides support for hypothesis 4 of the current investigation. This finding is consistent with those of previous researchers (for instance, Fishbein \& Coombs, 1974; Lim, 2001; Quah, 2000). 
Table 6

Comparison Of Goodness Of Measure

\begin{tabular}{|c|c|c|c|c|}
\hline Measure & Value & $\begin{array}{l}\text { Hit Ratio for } \\
\text { Analysis sample }\end{array}$ & Value & $\begin{array}{l}\text { Hit Ratio for } \\
\text { Holdout Sample }\end{array}$ \\
\hline $\begin{array}{l}\text { Maximum Chance } \\
\text { Proportional Chance }\end{array}$ & $\begin{array}{l}93.4 \% \\
87.7 \%\end{array}$ & $\begin{array}{l}95.2 \% \\
95.2 \%\end{array}$ & $\begin{array}{l}91.1 \% \\
83.7 \%\end{array}$ & $\begin{array}{l}98.0 \% \\
98.0 \%\end{array}$ \\
\hline $\begin{array}{l}\text { Press Q } \\
\text { Table Value } \\
\text { Calculated Value }\end{array}$ & & $\begin{array}{l}6.635 \\
65.33^{* *}\end{array}$ & & $\begin{array}{l}6.635 \\
52.07 * *\end{array}$ \\
\hline
\end{tabular}

** significant at $\mathrm{p}=0.01$

\section{DISCUSSION, LIMITATION, AND CONCLUSION}

The result from the multiple regression analysis showed that students' intention to choose a particular institution of higher learning (dependent variable) is indeed influenced by his/her attitude toward the behavior and the subjective social norms (independent variables). The value of $\mathrm{R}^{2}$ of 0.75 implies that the model has good predictive power. In other words, the two independent variables in combination were able to explain $75.0 \%$ variance in the dependent variable. Although both attitude and subjective social norms have significant influence on choice of higher learning institution, the weight assigned for each component, however, was not equal. From the beta coefficient, it can be seen that the attitude component has a higher value $(\beta=0.539)$ compared with the subjective social norm $(\beta=0.401)$. Thus, it can be concluded that the choice of a particular institution of higher learning stems from one's own rather than one's perception of the wishes and desires of important others (subjective norms).

In analyzing the rankings made by respondents on the important attributes associated with a particular higher learning institution, it can be observed for public higher learning institution, the two most important attributes were basically academic in nature (broad range of courses offered, and having a good academic reputation). For private higher learning institution, however, the two most important attributes were basically non-academic in nature (having a good social and learning atmosphere, and convenient location).

Generally, it can be observed that respondents ranked the item 'the broad range of courses offered' the highest, regardless of the types of institution of higher learning. This finding is consistent with the thinking of today's vocationalconscious students who view a higher learning institution as a place where they can gain specific skills and knowledge required in the job market. Additionally, respondents have ranked the item 'having a good social and learning atmosphere' as the second most important. This result indicates that students in this sample considered the contextual aspect of higher learning institutions as equally important to the academic content in pursuing a higher education. The findings from this study also show that students are more willing to comply with the opinions of their family, close friends, and teachers who had enrolled in higher learning institutions before. Furthermore, the result obtained from the discriminant analysis indicates that an individual student's intention can predict his/her behavior better than by chance. In other words, the model derived from the Theory of Reasoned Action is applicable in this study.

The study of student choice behavior contributes valuable information to higher learning 
institutions particularly the private higher learning institutions. Private colleges can make use of the information generated from this study as the point of departure to conduct their own studies. By understanding the consumer choice behavior, it could improve customer satisfaction and retention and thus opens opportunities for new services.

From a practical viewpoint, given the importance of the individual student's own attitude in influencing his/her choice to select a particular institution of higher learning, education marketers need to communicate clearly by providing all the pertinent information to the individual student instead of to those categorized as significant others. Since students consider both academic as well as non-academic factors in determining their choices intention, it would be beneficial for education marketers to incorporate the various contextual aspects such as a safe and conducive learning environment, opportunities for social interactions, extra curricular activities, up-to-date facilities, basic education infrastructure, and availability of financing in their advertisement and promotion campaigns. To summarize, in order to attract customers (students), the relevant authorities in institutions of higher learning should highlight the important academic and non-academic attributes and communicating this information clearly to their target audience.

One major limitation of this study relates to the small sample size where the students chosen were those studying in schools located in Penang alone. Future studies need to focus on students in other states which may enhance the generalizability of the findings.

\section{REFERENCES}

Absher, K., \& Crawford, G. (1996). Marketing the community college starts with understanding students' perspectives, Community College Review, 23(4), 59-68.

Ahmat, S. (1980). Nation building and the university in developing countries: The case of Malaysia, Journal of Higher Education, 9, 721-724.
Ahmed, F. (1996). The marketing of health care services; The choice of public and private maternity clinics, Unpublished MBA thesis, Penang: Universiti Sains Malaysia.

Ajzen, I., \& Fishbein, M. (1980). Understanding attitudes and predicting social behavior, New Jersey:Prentice-Hall.

Assael, H. (1992). Consumer Behavior \& Marketing Action, Massachusetts:PWS-Kent Publishing Company.

Brown, K. G. (1991). "Postsecondary Plan of High-School seniors in 1972 and 1980: Implications for Student Quality”, Denver: Paper presented at the Annual Forum of the Association for Institutional Research. ED 220060.25 pp, MF-01.

Fishbein, M., \& Coombs, F. S. (1974). Basis for decision: an attitudinal analysis of voting behavior, Journal of Applied Social Psychology, 4 (2), 95-124.

Fishbein, M., \& Ajzen, I. (1975). Belief, Attitude, Intention and Behavior : An Introduction to Theory and Research, Philippines:Addison-Wesley Publishing Company.

Gilmour, J. E. Jr., Dolich, I. J., \& Spiro, L. M. (1978). "How College Students Select a College", Houston: Paper presented to the Annual Forum of the Association for Institutional Research, ED 208 705. 39 pp. MF-01.

Hair, J. F. Jr., Anderson, R. E., Tatham, R. L., \& Black, W. C. (1998). Multivariate Data Analysis, New York:Prentice-Hall.

Holland, J. L. (1958). Student explanations of college choice and their relation to college productivity, and sex differences, College and University, 33, 313-320.

Hossler, D. (1984). Enrolment management: an integrated approach, The College Board: Washington, DC. 
Hossler, D., \& Gallagher, K. S. (1987). Studying student college choice: A three-phase model and the implications for policy makers, College and University, 2(3), 207-221.

Jackson, G. A. (1982). Public efficiency and private choice in higher education, Educational Evaluation and Policy Analysis, 4(2), 237247.

Kotler, P. (1994). Marketing Management, New Jersey: Prentice-Hall.

Kotler, P., \& Andreasen, A. (1991). Strategic Marketing for Nonprofit Organizations, New Jersey:Prentice-Hall.

Kotler, P., \& Fox, K. (1985). Strategic Marketing for Educational Institutions, New Jersey:Prentice-Hall.

Lewis, G., \& Morrison, S. (1975). "A Longitudinal Study of College Selection. Technical Report No. 2", Mimeograph, Pittsburgh: School of Urban and Public Affairs, CarnegieMellon University.

Lim, S. B. (2001). An Investigation of Penang's Resident Perception and Attitudes Towards Gambling Activities and Industry, Unpublished MBA thesis, Penang: Universiti Sains Malaysia.

Litten, L. H., \& Brodigan, D. I. (1982). "On Being Heard in a Noisy World: Matching Media and Messages in College Marketing.", College and University, 57(3): 242-263.

Litten, L. H., Sullivan, D., \& Brodigan, D. L. (1983). Applying Marketing Research in College Admissions, New York: College Entrance Examination Board
Litten, L. M. (1982). Different strokes in the applicant pool: Some refinements in a model of student college choice, Journal of Higher Education, 53(4), 383-402.

Nalliah, M., \& Thiyagarajah, R.,(1999). Malaysia: Review of Educational Events in 1998, Asia Pacific Journal of Education, 19(2), 95102.

New Straits Times, (1998, July, 21).

New Straits Times, (1998, November, 29).

Nunally, J.C. (1978). Psychometric Theory, New York: McGraw-Hill.

Quah, B. S. (2000). Consumer Choice Behavior. A Study of Consumer Choice Preference on Infant Formula. Unpublished MBA thesis, Penang: Universiti Sains Malaysia.

Schiffman, L., \& Kanuk, L. (1994). Consumer Behavior, New Jersey:Prentice-Hall.

Sheppard, B., Hartwick, J., \& Warshaw, P. (1988). The Theory of Reasoned Action: A MetaAnalysis of Past Research with Recommendations for Modifications and Future Research, Journal of Consumer Research, 15, 325-340.

Stanley, G., \& Reynolds, P. (1994). The relationship between students' level of school achievement, their preferences for future enrolment and their images of universities, Journal of Higher Education, 27, 85-93.

The Sun, (2000, January,16). 